\title{
TEORI EKONOMI DAVID RICARDO, THOMAS MALTUS DAN JB. SAY
}

\author{
Fitrah Rahma Inayah/90100118034
}

Mazhab klasik muncul kisaran tahun 1780-1850. Pemikiran klasik ini bisa dianggap sebagai dasar munculnya ekonomi kapitalis, dimana campur tangan pemerintah hanya sebagian kecil kepada kepentingan negara atau pemerintah, dimana salah satu tokoh ekonomi kapitalis yang terkenal yaitu Adam Smith. Pada dasarnya pemikiran ekonomi aliran klasik menganjurkan kebebasan alamiah, kepentingan diri, dan persaingan. Beberapa tokoh lain yang mendukung pemikiran Adam Smith adalah David Ricardo, Thomas Robert Malthus, dan Jean Baptiste Say (Faruq and Mulyanto, 2017).

\section{Teori Ekonomi David Ricardo}

David Ricardo berasal lahir di London pada tahun 1772. David tertarik dengan ilmu ekonomi dimulai sejak 1799, ketika dia tinggal di Bath saat dia mulai membaca The Wealth of Nation Adam Smith. David di usianya ke 42, ia telah menjadi seorang pengusaha sukse dan menjadi tuan tanah desa. Pada tahun 1817 dia mempublikasikan buku karya yang berjudul "On the Principle of Political Economy and Taxation" (Faruq and Mulyanto, 2017).

Teori Ricardo yang terkenal adalah tentang teori keunggulan komparatif, diamna perdagangan tergantung pada keunggulan komparatif atau efisiensi relatif dari pada keunggulan absolut. Ricardo menganggap bahwa negara akan cenderung menjual barangnya yang relatif lebih efisien dalam produksinya. Sehingga melalui spesialisasi, setiap negara akan memperoleh keuntungan dari perdagangan luar negeri (Atmanti, 2017).

David Ricardo juga memperkenalkan teori nilai kerja. Teori ini ia jelaskan bahwa nilai tukar suatu barang ditentukan oleh ongkos yang perlu dikeluarkan untuk menghasilkan barang tersebut. Ricardo menganggap baahwa biaya untuk bahan mentah dan upah buruh yang besarnya hanya cukup untuk bertahan hidup bagi buruh yang bersangkutan. Ricardo lebih menekankan pada maksimalisasi hasil produksi dan minimalisasi ongkos produksi dengan memberikan upah minimum bagi buruh (Aryanti, 2018). 
David Ricardo dan penekanannya terhadap sektor ekonomi menyebabkan pemikirannya sejalan dengan pemikiran ekonomi lainnya seperti Adam Smith dan Karl Marx. David Ricardo memuju premis dasar mereka yang menyatakan bahwa tenaga kerja itu merupakan sumber deluruh kekayaan. Maka atas dasar itulah David merumuskan teori nilai kerja. Dvid mengungkapkan bahwa "keuntungan kapitalis menjadi basis eksploitasi tenaga kerja" (Cholidiyah, 2018).

\section{Teori Ekonomi Thomas Malthus}

Thomas Malthus dilahirkan pada tanggal 13 Februari 1766 di Surrey, Inggris. Beberapa karya Malthus yang terkenal adalah bukunya yang berjudul Essay on Population yang dicetak pertama kali pada tahun 1978. Selain itu, Malthus juga menghabiskan sisa hidupnya untuk mempertahankan dan merevisi tesis overpopulasinya. Dia juga menulis banyak buku, seperti The Principles of Political Eonomy pada tahun 1820 (Faruq and Mulyanto, 2017).

Thomas Robert Maltus merupakan orang yang pertama kali memperkenalkan tentang kekhawatiran terhadap krisis. Ia menjelaskan bahwa laju pertambahan penduduk meningkat berdasarkan deret ukur, sedangkan produksi pangan berdasar deret hitung (Muna and Qomar, 2020). Selain itu, ia juga menyampaikan teorinya terkait asuransi, dimana ia menjelaskan pada reasuransi konvensioanl, kontrak antar kedua belah pihak yang dijamin membayar premi asuransi kepada pihak perusahaan reasuransi. Ia juga menjelaskan bahwa dalam hal asuransi konvensional tercermin adanya peran dan fungsi individu untuk saling membantu secara kolektif dalam hal pertarungan. Pandanngan ini dikenal dengan istilah teori fungsional ekonomi (Yusup, 2014).

\section{Teori Ekonomi JB. Say}

Jean Baptiste Say adalah tokoh ekonomi penting Perancis yang lahir di Lyon, Perancis pada tahun 1767. Tahun 1799 ia menjadi anggota Tribunat Napoleon, dimana saat itu Napoleon merupakan diktator yang hasu kekuasaan. Tahun 1806 terbit karya Say yang berjudul A Treastise on Political Economy, or the Production, Distribution, and Consumtion of Wealth (Faruq and Mulyanto, 2017). 
JB. Say mengembangkan pemikiran tentang kewirausahaan pada abad ke19, dimana ia memberikan kontribusi signifikan terhadap teori tersebut. Say melanjutkan konsep Cantillon yang menempatkan kewirausahaan sebagai pusat dari aktivitas perekonomian. Pemikiran Say ini dianggap lebih maju, lengpak dan lebih revolusioner dari konsep kewirausahaan Cantillon, bahkan Say memberikan sebuah model dari kewirausahaan yang didukung oleh kewirausahaan ekonomi pasar, kemandirian, dan pencarian keuntungan (Mintardjo et al. 2020). Menurut JB. Say, pengusaha yang mampu mengelola sumber daya yang dimiliki secara ekonomis (efektif dan efisien) dan tingkat produktivitas rendah menjadi lebih tinggi (Rahmasari, 2018). 


\section{DAFTAR PUSTAKA}

Atmanti, H. D. (2017). Kajian Teori Pemikiran Ekonomi Mazhab Klasik dan Relevansinya pada Perekonomian Indonesia. JEB17: Jurnal Ekonomi dan Bisnis, 2(02).

Aryanti, Y. (2018). Pemikiran Ekonomi Ibn Khaldun; Pendekatan Dinamika Sosial Ekonomi dan Politik. Imara: Jurnal Riset Ekonomi Islam, 2(2).

Cholidiyah, N. (2018). Perilaku Produsen Menurut Yusuf Qordhowi dan Karl Marx. Laa Maisyir: Jurnal Ekonomi Islam, 5(2).

Faruq, U. A., \& Mulyanto, E. Sejarah Teori-Teori Ekonomi. Banten: Unpam Press, 2017.

Mintardjo, C. M., Kawung, G. M., \& Raintung, M. C. (2020). SEJARAH TEORI KEWIRAUSAHAAN: DARI SAUDAGAR SAMPAI KE TEKNOPRENUR STARTUP. JMBI UNSRAT (Jurnal Ilmiah Manajemen Bisnis dan Inovasi Universitas Sam Ratulangi)., 7(2).

Muna, T. I., \& Qomar, M. N. (2020). Relevansi Teori Scarcity Robert Malthus Dalam Perspektif Ekonomi Syariah. SERAMBI: Jurnal Ekonomi Manajemen dan Bisnis Islam, 2(1), 1-14.

Rahmasari, I. P. (2018). Strategi Pengusaha Dalam Mengembangkan Usaha Kecil Batik Gajah Mada di Desa Mojosari Kecamatan Kauffman Kabupaten Tulungagung.

Subair, S. (2018). RELEVANSI TEORI MALTHUS DALAM DISKURSUS KEPENDUDUKAN KONTEMPORER. DIALEKTIKA, 9(2).

Yusup, D. K. (2014). PERBANDINGAN TEORI ASURANSI: STUDI PERBANDINGAN TEORI EKONOMI TAQIYYUDDÎN AL-NABANI DAN THOMAS ROBERT MALTUS. Asy-Syari'ah, 16(2), 145-158. 